\title{
RELATIONSHIP BETWEEN TYPE III SECRETION TOXINS, BIOFILM FORMATION, AND ANTIBIOTIC RESISTANCE IN CLINICAL PSEUDOMONAS AERUGINOSA ISOLATES
}

\author{
S. Derakhshan, A. Rezaee, Sh. Mohammadi \\ Kurdistan University of Medical Sciences, Sanandaj, Iran
}

\begin{abstract}
Background and aim. Pseudomonas aeruginosa is considered as a notorious pathogen due to its multidrug resistance and life threatening infections. We investigated the relationship between type III secretion toxins, biofilm formation, and antibiotic resistance among clinical P. aeruginosa isolates. Methods. A total of 70 genetically distinct clinical P. aeruginosa isolates were characterized for antibiotic resistance by disk diffusion assay. Biofilm formation was evaluated by microtiter plate method and presence of four exo genes (exoS, exoU, exoT and exoY) was investigated by PCR. A p-value $<0.05$ was regarded statistically significant. Results. The most effective antibiotics were Meropenem and Piperacillin. Multidrug resistance was more prevalent in the ciprofloxacin-resistant isolates than in the susceptible isolates. The most frequently identified exo was exoS (37.1\%). Genotype exoS/exoT was found in 4 isolates, while genotype exoU/exoT was not found. Prevalence of exoS was generally higher in the susceptible isolates than in the resistant isolates. A significant association was found between the formation of strong biofilm and resistance to antibiotics ( $\mathrm{p}<0.05)$. Prevalence of exoY and exo $U$ was higher in the non-strong biofilm producers compared to the strong biofilm producers. Conclusion. Our study revealed formation of strong biofilm along with antibiotic resistance and the presence of exo genes in P. aeruginosa isolates. Knowledge of virulence gene profiles and biofilm formation may be useful in deciding appropriate treatment.
\end{abstract}

Key words: Pseudomonas aeruginosa, biofilm, type III secretion system, drug resistance, virulence, exoenzyme.

\section{ВЗАИМОСВЯЗЬ МЕЖДУ ТОКСИНАМИ ІІІ ТИПА СЕКРЕЦИИ, ОБРАЗОВАНИЕМ БИОПЛЕНКИ И АНТИБИОТИЧЕСКОЙ РЕЗИСТЕНТНОСТЬЮ В КЛИНИЧЕСКИХ ИЗОЛЯТАХ РSЕUDОМОNАS AERUGINOSA}

Деракшан С., Резайи А., Мохаммади Ш.

Курдский университет медицинских наук, г. Сенендедж, Иран

Резюме. Актуальность и цель. Pseudomonas aeruginosa считается опасным патогеном из-за своей множественной лекарственной устойчивости и вызываемых им инфекций, представляющих угрозу для жизни. Мы исследовали взаимосвязь между токсинами секреции III типа, образованием биопленок и устойчивостью к антибиотикам среди клинических изолятов P. aeruginosa. Memoды. Диско-диффузионный анализ был использован для оценки устойчивости к антибиотикам у 70 генетически различных клинических изолятов P. aeruginosa. Образование биопленок оценивали в микротитрационном планшете, а наличие четырех экзогенов (exo $S$, exoU, exoT

\author{
Адрес для переписки: \\ Сафура Деракшан \\ Иран, г. Сенендедж, Курдский университет медицинских наук. \\ Тел.: +98 8733668504 \\ E-mail: s.derakhshan@muk.ac.ir
}

\author{
Contacts: \\ Safoura Derakhshan \\ Iran, Sanandaj, Kurdistan University of Medical Sciences. \\ Phone: +98 8733668504 \\ E-mail: s.derakhshan@muk.ac.ir
}

\section{Для цитирования:}

Деракшан С., Резайи А., Мохаммади Ш. Взаимосвязь между токсинами III типа секреции, образованием биопленки и антибиотической резистентностью в клинических изолятах Pseudomonas aeruginosa // Инфекция и иммунитет. 2021. Т. 11, № 6. С. 1075-1082. doi: 10.15789/2220-7619-RBT-1761

\section{Citation:}

Derakhshan S., Rezaee A., Mohammadi Sh. Relationship between type III secretion toxins, biofilm formation, and antibiotic resistance in clinical Pseudomonas aeruginosa isolates // Russian Journal of Infection and Immunity = Infektsiya i immunitet, 2021, vol. 11, no. 6, pp. 1075-1082. doi: 10.15789/2220-7619-RBT-1761 
и ехоY) исследовали с помощью полимеразной цепной реакции. Значение $\mathrm{p}<0,05$ считалось статистически значимым. Результаты. Наиболее эффективными антибиотиками оказались меропенем и пиперациллин. Множественная лекарственная устойчивость была более распространена у устойчивых, чем у чувствительных к ципрофлоксацину изолятов. Наиболее часто выявляемым экзоном был еxoS (37,1\%). Генотип exoS/exoT обнаружен у 4 изолятов, генотип ехоU/ехоT не выявлялся. Распространенность ехоS, как правило, была выше у чувствительных изолятов, чем у устойчивых. Была обнаружена достоверная связь между образованием прочной биопленки и устойчивостью к антибиотикам (р < 0,05). Распространенность ехоY и ехоU была выше у продуцентов непрочных биопленок, чем у продуцентов прочных биопленок. Заключение. Наше исследование, наряду с устойчивостью к антибиотикам и наличием экзогенов, выявило у изолятов P. aeruginosa способность к формированию прочной биопленки. Знание профиля генов вирулентности и образования биопленок может быть полезно при выборе соответствующего лечения.

Ключевые слова: Pseudomonas aеruginosa, биопленка, система секреции III типа, лекарственная устойчивость, вирулентность, экзофермент.

\section{Introduction}

Pseudomonas aeruginosa is a ubiquitous gramnegative bacterium capable of causing a wide range of diseases. Prominence of $P$. aeruginosa as a life threatening and a successful opportunistic pathogen is attributed to production of a diverse repertoire of virulence factors and its high resistance to diverse classes of antimicrobial agents [29]. Aminoglycosides, beta-lactams, and fluoroquinolones are three major classes of current anti-pseudomonal agents. Among these, fluoroquinolones are the best available agents for treatment. However, resistance to fluoroquinolones among $P$. aeruginosa has risen dramatically. More seriously, resistance to fluoroquinolones is often associated with cross-resistance to other antibiotics [14].

Furthermore, $P$. aeruginosa is well equipped with numerous pathogenic factors contributing to its virulence. Many of these factors are variable traits and their prevalence may vary from one type of infection to another type (i.e. they are present in some isolates but not in others) [20]. Type III secretion system (T3SS) is an important virulence determinant of $P$. aeruginosa that injects four exotoxins directly into host cells: Exoenzyme $\mathrm{S}$ (ExoS), Exoenzyme $\mathrm{U}$ (ExoU), Exoenzyme T (ExoT), and Exoenzyme Y (ExoY). The first identified $P$. aeruginosa T3SS toxins, ExoT and ExoS are closely related bifunctional proteins which are able to disrupt the host cell actin cytoskeleton, inhibit phagocytosis, induce host cell rounding, and cause cell death. ExoS and ExoT exhibit activity towards G-proteins of the Rho, Ras, Rac, and Cdc42 families [29]. ExoY is an adenylate cyclase that cleaves the intracellular cAMP in eukaryotic cells and causes cell rounding upon cocultivation with tissue culture cells. The fourth and the most virulent effector, ExoU, possesses phospholipase activity and disrupts eukaryotic membranes in many cell types. $P$. aeruginosa strains can be divided into two groups. ExoU and ExoT producing strains are poorly internalized and cause rapid host cell death. While, ExoS and ExoT producing strains are more efficiently internalized and cause slower cell killing. $P$. aeruginosa strains contain either exoU or exo $S$, but rarely both [10]. Additionally, some studies reported that exoS+ and exoU+ strains have different antibiotic resistance patterns [29, 30]; therefore, they may require different therapeutic strategies.

Tendency to form biofilms in $P$. aeruginosa has also been correlated with its ability to cause severe infections. One of the main components of these biofilms is an exopolysaccharide called alginate, which is encoded by $\operatorname{alg} D$ gene. The ability of $P$. aeruginos to form biofilm further complicates the problem of its high antimicrobial resistance [20].

Knowledge of drug resistance patterns can be helpful in understanding and predicting clinical outcomes of patients and information about virulence gene profiles and biofilm formation may be useful for deciding appropriate antibiotic treatment. Given the importance of T3SS and biofilm in the pathogenesis of $P$. aeruginosa infections, this study was performed to determine relationship between T3SS toxins-encoding genes, antibiotic resistance, and biofilm formation in clinical $P$. aeruginosa isolates.

\section{Materials and methods}

Bacterial isolates and identification. In this crosssectional study, $70 P$. aeruginosa isolates were collected from different specimens of patients admitted to two teaching hospitals in Sanandaj, Iran. Sanandaj is the capital of Kurdistan province in western Iran. Patients are referred to these two hospitals from all over the province. The isolates were identified as $P$. aeruginosa by the standard tests, including Gram staining, motility, pigment production, oxidase, hemolysis, odor, oxidation and fermentation test, lack of carbohydrate fermentation, and citrate assimilation [32]. The genetic diversity of the isolates was determined using the enterobacterial repetitive intergenic consensus (ERIC)-PCR [24].

The isolates were stored in Trypticase soy broth (TSB, Quelab Laboratories, Canada) containing $15 \%$ glycerol at $-70^{\circ} \mathrm{C}$ until further tests. This study was approved by Research Ethic Committee (REC) at Kurdistan University of Medical Sciences [IR. MUK.REC.1396.328]. 
Antibiotic susceptibility test. Antimicrobial susceptibility of the isolates was determined by the disk diffusion method according to the 2019 Clinical and Laboratory Standards Institute (CLSI) guidelines [9]. The following antibiotic disks (all from Rosco, Denmark) from three antipseudomonal categories were tested: aminglycoside [Amikacin $(30 \mu \mathrm{g})$ and Gentamicin $(10 \mu \mathrm{g})]$, beta-lactam [Cefepime $(30 \mu \mathrm{g})$, Piperacillin $(100 \mu \mathrm{g})$, Aztreonam $(30 \mu \mathrm{g})$, Ceftazidime $(30 \mu \mathrm{g})$, Meropenem $(10 \mu \mathrm{g})$, and Imipenem $(10 \mu \mathrm{g})]$, and Fluoroquinolone [Ciprofloxacin $(5 \mu \mathrm{g})]$.

Briefly, Mueller-Hinton agar (Quelab Laboratories, Canada) plates were inoculated with the bacterial suspensions equal to the turbidity standard of 0.5 McFarland $\left(1.5 \times 10^{8}\right.$ colony forming unit $\left./ \mathrm{mL}\right)$. Antibiotic disks were placed onto the inoculated plates with the appropriate distance and the plates were then incubated at $35^{\circ} \mathrm{C}$ for $16-18 \mathrm{~h}$. The inhibition zones around the disks were measured and interpreted according to the 2019 CLSI criteria [9].

DNA extraction and detection of genes. Genomic DNA was extracted using the boiling method. Overnight cultures of the isolates in TSB were centrifuged and Tris-EDTA (TE) buffer was added to the pellets. The suspensions were boiled at $100^{\circ} \mathrm{C}$ for $10 \mathrm{~min}$ and centrifuged. The supernatants were then collected and after qualitative evaluation on agarose gel (SinaClon, Iran) and quantitative evaluation by measuring the absorbance at $260 \mathrm{~nm}$ and by calculating the ratio of 260/280 to determine purity, were used as the DNA templates for subsequent experiments. The ratio of 260/280 within the range of 1.62 indicated the purity of DNA [15].

The $\operatorname{alg} D$ and T3SS toxins-encoding genes exoY, exoS, exoT, and exoU were amplified by polymerase chain reaction (PCR) method using the specific primers shown in Table 1 . PCR reaction was performed in a total volume of $25 \mu \mathrm{L}$ as follows: $1 \mathrm{X}$ reaction buffer, $0.2 \mathrm{mM}$ of each $\mathrm{dNTP}, 0.4 \mu \mathrm{M}$ of each primer, $1.5 \mathrm{mM} \mathrm{MgCl}_{2}, 0.5 \mathrm{U}$ Taq DNA polymerase (SinaClon, Iran), and $3 \mu \mathrm{L}$ template DNA. The DNA was amplified in a thermal cycler (Eppendorf, Germany) using the following conditions: initial denaturation step $\left(94^{\circ} \mathrm{C}\right.$ for $\left.5 \mathrm{~min}\right)$, followed by 30 cycles of denaturation $\left(1 \mathrm{~min}\right.$ at $\left.94^{\circ} \mathrm{C}\right)$, annealing (1 min at different temperatures [Table 1]), and extension $\left(1 \mathrm{~min}\right.$ at $\left.72^{\circ} \mathrm{C}\right)$, with a final extension at $72^{\circ} \mathrm{C}$ for $5 \mathrm{~min}$.
The PCR products were analyzed by electrophoresis on a $1.5 \%$ agarose gel in $0.5 \mathrm{X}$ Tris-Borate EDTA (TBE) buffer, stained with Safe Stain (SinaClon) and visualized by UV transilluminator. A 100 bp Plus DNA ladder (SinaClon) was used as a size marker.

Biofilm formation assay. Biofilm formation was performed according to the method of O'Toole [22]. Overnight cultures of the isolates were diluted to the turbidity equal to a McFarland 0.5 standard in TSB medium and $100 \mu \mathrm{L}$ of the each dilution were loaded into the wells of a flat-bottom 96-well microtiter plate (Jet Biofil, China). After $24 \mathrm{~h}$ incubation at $37^{\circ} \mathrm{C}$ for biofilm formation, the supernatants were removed and the wells were washed twice with distilled water. After discarding the planktonic cells, the wells were stained with an aqueous solution of crystal violet $(0.1 \%, \mathrm{w} / \mathrm{v})$ for $15 \mathrm{~min}$ at room temperature and washed twice with distilled water. The microtiter plates were then dried for a few hours. The bound dye was solubilized in $125 \mu \mathrm{L}$ of $30 \%$ (v/v) acetic acid and the plates were kept for $15 \mathrm{~min}$ at room temperature to extract bound dye. The optical density (OD) of each well was measured by using a microplate reader (Anthos Labtec, Netherlands) at $550 \mathrm{~nm}$. S. aureus ATCC 25923 (biofilm forming) and Staphylococcus epidermidis ATCC 12228 (not biofilm-forming) were used as controls. Sterile TSB was used as the negative control. For biofilm formation assay, 4 wells per strain were used and each test was repeated three times.

Biofilm density was classified according to the scheme of Stepanovic et al. [27]. The cut-off value (ODc) for each microtiter plate was defined as three standard deviations (SD) above the mean OD of the negative control: ODc $=$ average OD of negative controls $+(3 \times \mathrm{SD}$ of negative controls $)$. Isolates were then classified into the following categories, based on the average OD of the strain:

$\mathrm{OD} \leq \mathrm{ODc}=$ no biofilm producer;

$\mathrm{ODc} \leq \mathrm{OD} \leq 2 \mathrm{OD} \mathrm{c}=$ weak biofilm producer;

$2 \mathrm{ODc} \leq \mathrm{OD} \leq 4 \mathrm{ODc}=$ moderate biofilm producer; $4 \mathrm{ODc} \leq \mathrm{OD}=$ strong biofilm producer.

Statistical analysis. SPSS software version 16 (SPSS Inc., USA) was used for statistical analysis. Pearson chi-square test and Fisher's exact test (where appropriate) were used to determine the relationships. A p-value $<0.05$ was regarded statistically significant. Multidrug-resistant (MDR) was defined as non-

Table 1. Primer sequences, annealing temperatures and expected amplicon size

\begin{tabular}{|c|c|c|c|c|}
\hline $\begin{array}{c}\text { Target } \\
\text { gene }\end{array}$ & Primer sequence $\left(\mathbf{5}^{\prime} \rightarrow \mathbf{3}^{\prime} \mathbf{)}\right.$ & $\begin{array}{c}\text { Annealing } \\
\text { temperature }\left({ }^{\circ} \mathbf{C}\right)\end{array}$ & $\begin{array}{c}\text { Size } \\
\text { of fragments (bp) }\end{array}$ & Reference \\
\hline exoS & CTTGAAGGGACTCGACAAGG/TTCAGGTCCGCGTAGTGAAT & 58 & 504 & {$[7]$} \\
\hline exoU & CCGTTGTGGTGCCGTTGAAG/CCAGATGTTCACCGACTCGC & 61 & 134 & {$[7]$} \\
\hline exoT & CAATCATCTCAGCAGAACCC/TGTCGTAGAGGATCTCCTG & 55 & 1159 & {$[3]$} \\
\hline exoY & TATCGACGGTCATCGTCAGGT/TTGATGCACTCGACCAGCAAG & 61 & 1035 & {$[3]$} \\
\hline algD & ATGCGAATCAGCATCTTTGGT/CTACCAGCAGATGCCCTCGGC & 57 & 1310 & {$[7]$} \\
\hline
\end{tabular}


Table 2. Antimicrobial cross resistance pattern of ciprofloxacin-resistant versus ciprofloxacinsusceptible isolates of clinical Pseudomonas aeruginosa

\begin{tabular}{|c|c|c|c|c|}
\hline Agents & $\begin{array}{c}\text { Resistance } \\
\text { pattern }\end{array}$ & 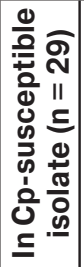 & 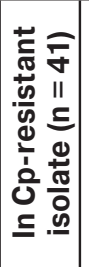 & 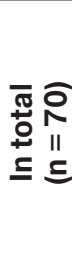 \\
\hline \multirow{2}{*}{ One } & $\mathrm{Cp}$ & 0 & 1 & 1 \\
\hline & $\mathrm{Gm}$ & 6 & 0 & 6 \\
\hline \multirow{2}{*}{ Two } & AT, Cp & 0 & 2 & 2 \\
\hline & $\mathrm{Cp}, \mathrm{Gm}$ & 0 & 10 & 10 \\
\hline Three & $\mathrm{Ak}, \mathrm{Cp}, \mathrm{Gm}$ & 0 & 1 & 1 \\
\hline \multirow{6}{*}{$\begin{array}{l}\text { Three, } \\
\text { MDR }^{\star}\end{array}$} & PM, AT, Cp & 0 & 1 & 1 \\
\hline & AT, IP, Gm & 1 & 0 & 1 \\
\hline & $\mathrm{PM}, \mathrm{Cp}, \mathrm{Gm}$ & 0 & 1 & 1 \\
\hline & $\mathrm{Cp}, \mathrm{Gm}, \mathrm{Pi}$ & 0 & 1 & 1 \\
\hline & AT, IP, Pi & 1 & 0 & 1 \\
\hline & AT, Cp, Gm & 0 & 1 & 1 \\
\hline \multirow{4}{*}{$\begin{array}{l}\text { Five, } \\
\text { MDR }\end{array}$} & PM, AT, Cp, IP, MP & 0 & 1 & 1 \\
\hline & TZ, PM, AT, Cp, Gm & 0 & 5 & 5 \\
\hline & Ak, AT, Cp, IP, Gm & 0 & 1 & 1 \\
\hline & $\mathrm{Ak}, \mathrm{AT}, \mathrm{Cp}, \mathrm{Gm}, \mathrm{Pi}$ & 0 & 1 & 1 \\
\hline \multirow{4}{*}{$\begin{array}{l}\text { Six } \\
\text { MDR }\end{array}$} & Ak, AT, Cp, IP, MP, Gm & 0 & 1 & 1 \\
\hline & Ak, PM, AT, Cp, IP, Gm & 0 & 1 & 1 \\
\hline & TZ, Ak, PM, AT, Cp, Gm & 0 & 1 & 1 \\
\hline & TZ, PM, AT, Cp, IP, Gm & 0 & 1 & 1 \\
\hline \multirow{3}{*}{$\begin{array}{l}\text { Seven, } \\
\text { MDR }\end{array}$} & TZ, Ak, PM, AT, Cp, IP, Gm & 0 & 1 & 1 \\
\hline & TZ, Ak, PM, AT, Cp, Gm, Pi & 0 & 2 & 2 \\
\hline & TZ, Ak, AT, Cp, IP, Gm, Pi & 0 & 1 & 1 \\
\hline \multirow{4}{*}{$\begin{array}{l}\text { Eight, } \\
\text { MDR }\end{array}$} & Ak, PM, AT, Cp, IP, MP, Gm, Pi & 0 & 1 & 1 \\
\hline & TZ, PM, AT, Cp, IP, MP, Gm, Pi & 0 & 2 & 2 \\
\hline & TZ, Ak, PM, AT, Cp, IP, MP, Gm & 0 & 1 & 1 \\
\hline & TZ, Ak, PM, AT, Cp, IP, Gm, Pi & 0 & 1 & 1 \\
\hline $\begin{array}{l}\text { Nine, } \\
\text { MDR }\end{array}$ & TZ, Ak, PM, AT, Cp, IP, MP, Gm, Pi & 0 & 2 & 2 \\
\hline
\end{tabular}

Note. $\mathrm{Cp}$ - Ciprofloxacin, $\mathrm{Pi}$ - Piperacillin, AT - Aztreonam, IP - Imipenem, MP - Meropenem, TZ - Ceftazidime, PM - Cefepime, $\mathrm{Gm}-$ Gentamicin, Ak - Amikacin. ${ }^{*} \mathrm{MDR}$ - multidrug resistant.

Table 3. Virulence patterns of 70 clinical Pseudomonas aeruginosa isolates

\begin{tabular}{|l|c|}
\hline \multicolumn{1}{|c|}{ Virulence pattern } & Isolates, $\mathbf{N}(\%)$ \\
\hline exoS+, exoY-, exoT-, exoU-, algD- & $15(21.4)$ \\
\hline exoS+, exoY+, exoT-, exoU-, algD- & $5(7.1)$ \\
\hline exoS-, exoY-, exoT-, exoU+, algD- & $4(5.7)$ \\
\hline exoS+, exoY+, exoT+, exoU-, algD- & $2(2.85)$ \\
\hline exoS+, exoY-, exoT+, exoU-, algD- & $2(2.85)$ \\
\hline exoS+, exoY-, exoT-, exoU-, algD+ & $2(2.85)$ \\
\hline exoS-, exoY-, exoT-, exoU-, algD+ & $2(2.85)$ \\
\hline exoS-, exoY-, exoT-, exoU+, algD+ & $1(1.4)$ \\
\hline exoS-, exoY+, exoT-, exoU-, algD- & $1(1.4)$ \\
\hline exoS-, exoY+, exoT-, exoU+, algD- & $1(1.4)$ \\
\hline exoS-, exoY-, exoT-, exoU-, algD- & $35(50)$ \\
\hline
\end{tabular}

susceptible isolates to at least one agent in three or more different antimicrobial categories [18]. The isolates were classified as strong biofilm producers or non-strong (moderate and weak) biofilm producers for statistical purposes [13].

\section{Results}

In this study, 70 genetically distinct strains of $P$. aeruginosa were isolated from different clinical specimens. The mean age of the patients was 56.3 years old. The youngest patient was a 27 year old male and the oldest was a 91 year old male. The age distribution of patients was as follows: 27-46 years $(\mathrm{n}=22,31.4 \%), 47-66$ years $(\mathrm{n}=30,42.8 \%)$, and $67-86$ years $(\mathrm{n}=16,22.8 \%)$.

Of the 70 isolates, $47(67.1 \%)$ were isolated from males and $23(32.9 \%)$ were from females. The majority of the strains were isolated from urine $(\mathrm{n}=$ $54,77.1 \%)$ followed by tracheal secretions $(n=11$, $15.7 \%)$, and blood ( $\mathrm{n}=5,7.1 \%)$.

Determination of antibiotic susceptibility. The most effective antibiotics were Meropenem $(n=62,88.6 \%$ sensitivity) and Piperacillin ( $\mathrm{n}=58,82.8 \%$ sensitivity). They were excluded from statistical analysis of difference among groups. The sensitivity to other antibiotics was as follows: Amikacin 55 (78.6\%), Imipenem 54 (77.1\%), Ceftazidime 53 (75.7\%), Cefepime 49 (70\%), and Aztreonam 41 (58.6\%). The least effective antibiotics were Ciprofloxacin ( $\mathrm{n}=29,41.4 \%$ sensitivity) and Gentamicin ( $\mathrm{n}=27,38.6 \%$ sensitivity).

A total of 27 resistance patterns were detected in the 70 isolates, while 21 isolates $(30 \%)$ were susceptible to all tested antibiotics. The patterns ranged from resistance to one antibiotic to all the 9 antibiotics. Of the 70 isolates, 7 isolates $(10 \%)$ were resistant to one agent, $31(44.3 \%)$ to 2 to 6 agents, and 11 $(15.7 \%)$ isolates showed resistance to 7 to 9 agents. The most frequently detected pattern was resistance to Ciprofloxacin and Gentamicin combination $(10 / 70,14.3 \%)$ followed by resistance to Gentamicin $(6 / 70,8.6 \%)$. Of the 70 isolates, 29 were MDR (41.4\%). Co-resistance to three antipseudomonal categories (fluoroquinolone, beta-lactam, and aminoglycoside) was found in 25 of the 70 isolates $(35.7 \%$ ) (Table 2).

Furthermore, pattern of resistance to other antibiotics was determined in the Ciprofloxacin-susceptible and -resistant isolates (Table 2). In the 29 Ciprofloxacin-susceptible isolates, 8 isolates $(27.6 \%)$ were resistant to 1 to 3 agents and no isolate was resistant to 5 to 9 agents. However, in the 41 Ciprofloxacinresistant isolates, 18 isolates $(43.9 \%)$ were resistant to 1 to 3 agents, and 23 isolates $(56.1 \%)$ showed resistance to 5 to 9 agents. Multidrug resistance was found in 27 (65.9\%) of the 41 Ciprofloxacin-resistant isolates, while only 2 (6.9\%) of the 29 Ciprofloxacinsusceptible isolates were MDR.

Prevalence of genes. The genes encoding Exo toxins were found in 33 of the 70 isolates $(47.1 \%)$, 
while 35 isolates $(50 \%)$ carried no virulence genes. Of the 70 isolates, $26(37.1 \%)$ carried the exoS gene, $9(12.8 \%)$ the exoY, $6(8.6 \%)$ the exo $U$, and 4 isolates $(5.7 \%)$ carried the exoT gene. The $\operatorname{alg} D$ was found in 5 isolates $(7.1 \%)$. The simultaneous presence of two genes was found in 11 isolates and only 2 isolates carried three genes simultaneously (exoS, exoY, and exoT). Both strains were isolated from urine and showed susceptibility to all tested antibiotics. No isolate carried the simultaneous presence of four or five genes. Genotype exoS/exoT was found in 4 isolates, while genotype exoU/exoT was not found. None of the exoUt isolates harbored the exoS (Table 3).

Because there are studies that reported exoS+ and exoUt strains have different antibiotic resistance patterns [29, 30]; we determined the prevalence of exoS in the antibiotic-susceptible and -resistant isolates. With the exception of Gentamicin, the prevalence of exoS was higher in the susceptible isolates than in the resistant isolates, although it was not significant. The exoS was found more frequently in the isolates susceptible to Ciprofloxacin followed by Cefepime, Imipenem, and Amikacin (Fig. 1). Multidrug resistance was found in 10 of the 26 exos+ isolates $(38.5 \%)$.

Biofilm assay. Of the 70 isolates studied, all formed biofilm; of which 35 isolates $(50 \%)$ formed strong biofilm, 28 isolates $(40 \%)$ moderate biofilm, and only 7 isolates (10\%) formed weak biofilm.

The resistant isolates formed strong biofilm more frequently compared to the susceptible isolates. The formation of strong biofilm was more frequently found in the isolates resistant to Cefepime followed by Ceftazidime, and Aztreonam. Significant associ-

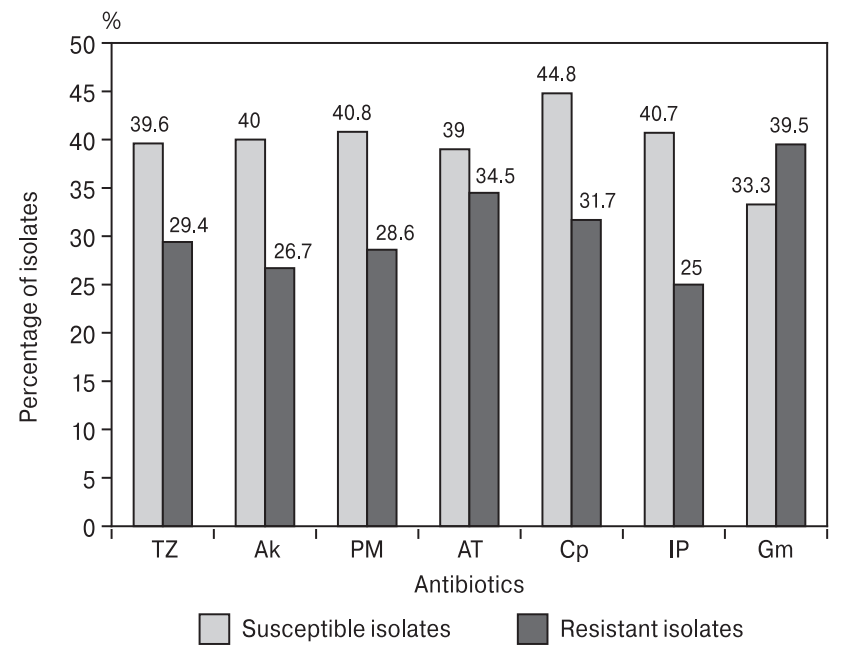

Figure 1. Prevalence of exoS virulence gene in antibiotic-resistant and antibiotic-susceptible isolates of $\mathbf{7 0}$ clinical Pseudomonas aeruginosa Note. TZ - Ceftazidime, Ak - Amikacin, PM - Cefepime, AT - Aztreonam, Cp - Ciprofloxacin, IP - Imipenem, Gm - Gentamicin. ations were seen between formation of strong biofilm and resistance to Cefepime $(\mathrm{P}=0.019)$, Aztreonam $(P=0.008)$, and Ciprofloxacin $(P=0.008)$ (Fig. 2).

In addition, the prevalence of exo genes was determined in the 35 strong and the 35 non-strong (moderate + weak) biofilm producers. The exoS and exoT were equally distributed between the two groups (37.1\% and $5.7 \%$, respectively); however, the prevalence of exoY and exoU was higher in the non-strong biofilm producers compared to the strong biofilm producers (20\% vs. $5.7 \%$ for the exoY, and $11.4 \%$ vs. $5.7 \%$ for the exoU, respectively). All of the five $a \lg D$-positive isolates formed strong biofilm.

\section{Discussion}

$P$. aeruginosa is considered as a notorious pathogen due to its multidrug resistance and life-threatening infections [29]. Our strains were mostly isolated from inpatients and the majority of patients $(42.8 \%)$ were between 47-66 years old, which can be explained by the fact that $P$. aeruginosa infections mostly occur in people in the hospital and/or with the weakened immune systems [4].

Fluoroquinolones, aminoglycosides, and beta lactams are three main antimicrobial classes with reliable antipseudomonal activity. Among these, fluoroquinolones are the best available treatment option [14]. A relatively high percentage of our isolates (58.6\%) showed resistance to ciprofloxacin which is in agreement with previous studies in Pakistan [25] and Egypt [2]. The widespread use of fluoroquinolones both in human and veterinary medicine may be responsible for the high resistances to this class. In addition, resistance to fluoroquinolones was significant-

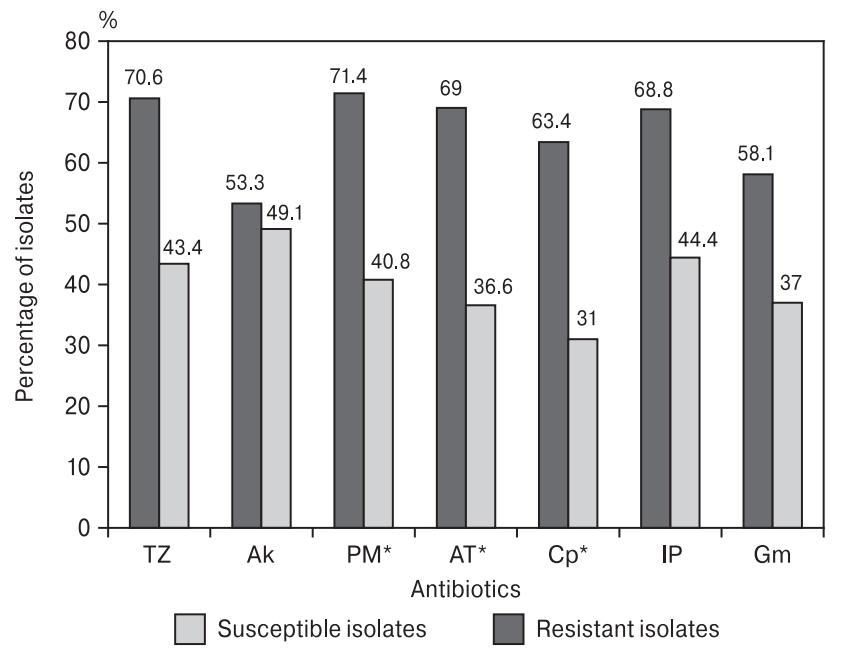

Figure 2. Prevalence of strong biofilm producers in antibiotic-resistant and susceptible isolates of clinical Pseudomonas aeruginosa

Note. TZ - Ceftazidime, Ak - Amikacin, PM - Cefepime, AT - Aztreonam, Cp - Ciprofloxacin, IP - Imipenem, $\mathrm{Gm}$ - Gentamicin. * - P-value less than 0.05 . 
ly associated with cross resistance to other agents [14]. In our study, MDR isolates were more frequently detected in the ciprofloxacin-resistant isolates.

$P$. aeruginosa is well equipped with numerous pathogenic factors contributing to its virulence. T3SS in $P$. aeruginosa is an important virulence factor that transports four proteins: ExoU, ExoS, ExoY and ExoT [29]. In our study, exoS showed the highest prevalence (37.1\%). In southern Iran [16] 35.8\% and in Bulgaria [28] 37.6\% of the isolates carried exoS, which were similar to our report. However, studies in central Iran and Poland reported the prevalence rates of $77.7 \%$ [19] and $88.4 \%$ [23] for exoS, respectively, which were higher than that in our study.

While in our work the prevalence of exoT was $5.7 \%$, which was similar to a study in northwestern Iran (5\%) [5], it was markedly lower than those reported by others. For example, in central Iran [12] and in Poland [23], the prevalence rates of 20.4 and $94.4 \%$ were reported, respectively. Moreover, we observed a low prevalence of the exoY (12.8\%); while, in the northwest of Iran, 55\% [5] and in India, 91.3\% [26] of $P$. aeruginosa isolates carried the exoY. The prevalence of the fourth gene, exoU in our study was $8.6 \%$. However, in a study from Iran a rate of $42.8 \%$ [19] and in Egypt a prevalence of $33 \%$ [2] were reported for exoU. The lower prevalence of exo genes in our study may be due to differences in the source of isolates or geographical regions. Many of the $P$. aeruginosa virulence factors are variable traits and they are found in some isolates, but not in others [20]. For example, Choy et al. reported that the exoU is commonly found in $P$. aeruginosa strains isolated from keratitis [8], whereas it occurs at low prevalence in the non-ocular isolates [30] or the prevalence of exo $S$ was significantly higher in isolates from blood than those obtained from respiratory infections [28]. In addition, it is possible that our strains were isolated from chronic infections. The expression of the T3SS has been found to be downregulated in isolates from chronic phase of infection, which is consistent with the notion that persistence of bacteria in the host requires the downregulation of many virulence factors [10].

In our study, a disagreement was seen in the distribution of exoS and exoU genes, in consistent with other studies $[10,29,30]$. The exo $U$ gene is located within a genomic island and its acquisition may cause loss of the exoS [17]. The T3SS system and its effectors were probably acquired by horizontal DNA transmission and antibiotic rich environments could promote the evolution of more virulent strains [10]. The prevalence of exoS in our study was generally higher in the susceptible isolates compared to the resistant isolates. The higher prevalence of this gene may contribute to the pathogenesis of antibiotic susceptible isolates. The exoS+ strains may be protected from the action of antibiotics due to their ability to invade mammalian cells and their residence inside cells [10]. Due to the small number of exoUt isolates, we couldn't determine association between the presence of exo $U$ and drug resistance; however, the presence of exoU has been correlated to antibiotic resistance phenotypes in $P$. aeruginosa $[1,30]$. The exoU+ strains may have a survival advantage by having the potential to be more resistant.

Biofilm production has been considered as an important determinant of pathogenicity in $P$. aeruginosa infections by facilitating the emergence of antimicrobial drug resistance and by generating chronic infections. The alginate is the most important component of $P$. aeruginosa biofilms [20]. A low prevalence of $\operatorname{alg} D$ (7.1\%) was found in our isolates. The prevalence rates of 0 to $98 \%$ were reported for $\operatorname{alg} D$ in different studies $[2,6,11]$. The low prevalence of $\operatorname{alg} D$ in our study might be attributed to the high number of strains isolated from UTI. There are reports that contribution of alginate in the urinary tract is thought to be minimal [21, 31]. In addition, production of some other exopolysaccharides like Psl and Pel may contribute to the formation of biofilm in $P$. aeruginosa [20]. The prevalence of strong biofilm producers in our study was higher in the resistant isolates than in the susceptible isolates, especially for cefepime, aztreonam, and ciprofloxacin. The ability to form strong biofilm along with resistance to antibiotics may cause high rates of failure in therapy of $P$. aeruginosa infections. Furthermore, we found that exoY $Y$ and exo $U$ were more prevalent in the non-strong biofilm producers. These results may indicate the importance of exoY and exoU in the pathogenesis of non-strong biofilm producers of $P$. aeruginosa.

\section{Conclusion}

In conclusion, findings of the present study showed a relatively different distribution of exo genes in clinical $P$. aeruginosa isolates from western Iran. The formation of strong biofilm along with antibiotic resistance and presence of exo genes may lead to severe diseases. Further in-depth studies are needed to determine whethergene linkage on mobile genetic elements underlies the relationships observed in our study. Knowledge of virulence gene profiles and biofilm formation may be useful for deciding appropriate treatment.

\section{References}

1. Agnello M., Finkel S.E., Wong-Beringer A. Fitness cost of fluoroquinolone resistance in clinical isolates of Pseudomonas aeruginosa differs by type III secretion genotype. Front Microbiol., 2016, vol. 7: 1591. doi: 10.3389/fmicb.2016.01591

2. Al Dawodeyah H.Y., Obeidat N., Abu-Qatouseh L.F., Shehabi A.A. Antimicrobial resistance and putative virulence genes of Pseudomonas aeruginosa isolates from patients with respiratory tract infection. Germs, 2018, vol. 8, no. 1, pp. 31-40. doi: 10.18683/germs.2018.1130 
3. Alonso B., Fernández-Barat L., Di Domenico E.G., Marín M., Cercenado E., Merino I., de Pablos M., Muñoz P., Guembe M. Characterization of the virulence of Pseudomonas aeruginosa strains causing ventilator-associated pneumonia. BMC Infect. Dis., 2020, vol. 20, no. 1: 909. doi: 10.1186/s12879-020-05534-1

4. Al-Wrafy F., Brzozowska E., Górska S., Gamian A. Pathogenic factors of Pseudomonas aeruginosa-the role of biofilm in pathogenicity and as a target for phage therapy. Postepy Hig. Med. Dosw. (Online), 2017, vol. 71, pp. 78-91. doi: 10.5604/01.3001.0010.3792

5. Azimi S., Kafil H.S., Baghi H.B., Shokrian S., Najaf K., Asgharzadeh M., Yousefi M., Shahrivar F., Aghazadeh M. Presence of exoY, exoS, exoU and exoT genes, antibiotic resistance and biofilm production among Pseudomonas aeruginosa isolates in Northwest Iran. GMS Hyg. Infect. Control, 2016, vol. 11: Doc04. doi: 10.3205/dgkh000264

6. Badamchi A., Masoumi H., Javadinia S., Asgarian R., Tabatabaee A. Molecular detection of six virulence genes in Pseudomonas aeruginosa isolates detected in children with urinary tract infection. Microb. Pathog., 2017, vol. 107: 44-47. doi: 10.1016/j.micpath.2017.03.009

7. Bogiel T., Depka D., Rzepka M., Kwiecińska-Piróg J., Gospodarek-Komkowska E. Prevalence of the genes associated with biofilm and toxins synthesis amongst the Pseudomonas aeruginosa clinical strains. Antibiotics, 2021, vol. 10, no. 3: 241. doi: 10.3390/ antibiotics10030241

8. Choy M.H., Stapleton F., Willcox M.D., Zhu H. Comparison of virulence factors in Pseudomonas aeruginosa strains isolated from contact lens-and non-contact lens-related keratitis. J. Med. Microbiol., 2008, vol. 57, no. 12, pp. 539-1546. doi: 10.1099/ jmm.0.2008/003723-0

9. CLSI. Performance standards for antimicrobial susceptibility testing. $30^{\text {th }}$ ed. Wayne: CLSI, 2019. $282 p$.

10. Engel J., Balachandran P. Role of Pseudomonas aeruginosa type III effectors in disease. Curr. Opin. Microbiol., 2009, vol. 12, no. 1, pp. 61-66. doi: 10.1016/j.mib.2008.12.007

11. Fazeli N., Momtaz H. Virulence gene profiles of multidrug-resistant Pseudomonas aeruginosa isolated from Iranian hospital infections. Iran Red. Crescent Med. J., 2014, vol. 16, no. 10: e15722. doi: 10.5812/ircmj.15722

12. Haghi F., Zeighami H., Monazami A., Toutouchi F., Nazaralian S., Naderi G. Diversity of virulence genes in multidrug resistant Pseudomonas aeruginosa isolated from burn wound infections. Microb. Pathog., 2018, vol. 115, pp. 251-256. doi: 10.1016/ j.micpath.2017.12.052

13. Horna G., Quezada K., Ramos S., Mosqueda N., Rubio M., Guerra H., Ruiz J. Specific type IV pili groups in clinical isolates of Pseudomonas aeruginosa. Int. Microbiol., 2019, vol. 22, no. 1, pp. 31-41. doi: 10.1007/s10123-018-00035-3

14. Hsu D.I., Okamoto M.P., Murthy R., Wong-Beringer A. Fluoroquinolone-resistant Pseudomonas aeruginosa: risk factors for acquisition and impact on outcomes. J. Antimicrob. Chemother., 2005, vol. 55, no. 4, pp. 535-541. doi: 10.1093/jac/dki026

15. Khare P., Raj V., Chandra S., Agarwal S. Quantitative and qualitative assessment of DNA extracted from saliva for its use in forensic identification. J. Forensic Dent. Sci., 2014, vol. 6, no. 2, pp. 81-85. doi: 10.4103/0975-1475.132529

16. Khoramrooz S.S., Rahbari N., Parhizgari N., Sharifi A., Yazdanpanah M., Gharibpour F., Rabani S.M., Malekhosseini S.A., Marashifard M. Frequency of type III secretion system cytotoxins-encoding genes among Pseudomonas aeruginosa isolated from burn patients. J. Adv. Med. Biomed Res., 2015, vol. 23, no. 99, pp. 52-63.

17. Kulasekara B.R., Kulasekara H.D., Wolfgang M.C., Stevens L., Frank D.W., Lory S. Acquisition and evolution of the exoU locus in Pseudomonas aeruginosa. J. Bacteriol., 2006, vol. 188, no. 11, pp. 4037-4050. doi: 10.1128/JB.02000-05

18. Magiorakos A.P., Srinivasan A., Carey R.B., Carmeli Y., Falagas M.E., Giske C.G., Harbarth S., Hindler J.F., Kahlmeter G., Olsson-Liljequist B., Paterson D.L. Multidrug-resistant, extensively drug-resistant and pandrug-resistant bacteria: an international expert proposal for interim standard definitions for acquired resistance. Clin. Microbiol. Infect. J., 2012, vol. 18, no. 3, pp. 268-281. doi: 10.1111/j.1469-0691.2011.03570.x

19. Mohamad M., Rostami S., Zamanzad B., Gholipour A., Deris F. Detection of exotoxins and antimicrobial susceptibility pattern in clinical Pseudomonas aeruginosa Isolates. Avicenna J. Clin. Microbiol. Infect., 2018, vol. 5, no. 2, pp. 36-40. doi: 10.34172/ ajcmi.2018.07

20. Moradali M.F., Ghods S., Rehm B.H. Pseudomonas aeruginosa lifestyle: a paradigm for adaptation, survival, and persistence. Front. Cell. Infect. Microbiol., 2017, vol. 7: 39. doi: 10.3389/fcimb.2017.00039

21. Newman J.W., Floyd R.V., Fothergill J.L. The contribution of Pseudomonas aeruginosa virulence factors and host factors in the establishment of urinary tract infections. FEMS Microbiology Letters, 2017, vol. 364, no. 15: fnx124. doi: 10.1093/femsle/fnx124

22. O'Toole G.A. Microtiter dish biofilm formation assay. J. Vis. Exp., 2011, vol. 47: 2437. doi: 10.3791/2437

23. Pobiega M., Chmielarczyk A., Kozioł J., Pomorska-Wesołowska M., Ziolkowski G., Romaniszyn D., Bulanda M., WojkowskaMach J. Virulence factors genes and drug resistance in Pseudomonas aeruginosa strains derived from different forms of community and healthcare associated infections. Postepy Hig. Med. Dosw., 2018, vol. 72, pp. 751-759. doi: 10.5604/01.3001.0012.2426

24. Saleem S., Bokhari H. Resistance profile of genetically distinct clinical Pseudomonas aeruginosa isolates from public hospitals in central Pakistan. J. Infect. Public Health, 2020, vol. 13, no. 4, pp. 598-605. doi: 10.1016/j.jiph.2019.08.019

25. Samad A., Ahmed T., Rahim A., Khalil A., Ali I. Antimicrobial susceptibility patterns of clinical isolates of Pseudomonas aeruginosa isolated from patients of respiratory tract infections in a Tertiary Care Hospital, Peshawar. Pak. J. Med. Sci., 2017, vol. 33, no. 3, pp. 670-674. doi: 10.12669/pjms.333.12416

26. Shariff M., Chhabra S.K., Rahman M.U. Similar virulence properties of infection and colonization associated Pseudomonas aeruginosa. J. Med. Microbiol., 2017, vol. 66, no. 10, pp. 1489-1498. doi: 10.1099/jmm.0.000569

27. Stepanović S., Vuković D., Hola V., Bonaventura G.D., Djukić S., Cirković I., Ruzicka F. Quantification of biofilm in microtiter plates: overview of testing conditions and practical recommendations for assessment of biofilm production by staphylococci. APMIS, 2007, vol. 115, no. 8, pp. 891-899. doi: 10.1111/j.1600-0463.2007.apm_630.x

28. Strateva T., Markova B., Ivanova D., Mitov I. Distribution of the type III effector proteins-encoding genes among nosocomial Pseudomonas aeruginosa isolates from Bulgaria. Ann. Microbiol., 2010, vol. 60, pp. 503-509. doi: 10.1007/s13213-010-0079-3

29. Strateva T., Mitov I. Contribution of an arsenal of virulence factors to pathogenesis of Pseudomonas aeruginosa infections. Ann. Microbiol., 2011, vol. 61, pp. 717-732. doi: 10.1007/s13213-011-0273-y 
30. Subedi D., Vijay A.K., Kohli G.S., Rice S.A., Willcox M. Association between possession of ExoU and antibiotic resistance in Pseudomonas aeruginosa. PLoS One, 2018, vol. 13, no. 9: e0204936. doi: 10.1371/journal.pone.0204936

31. Tielen P., Narten M., Rosin N., Biegler I., Haddad I., Hogardt M., Neubauer R., Schobert M., Wiehlmann L., Jahn D. Genotypic and phenotypic characterization of Pseudomonas aeruginosa isolates from urinary tract infections. Int. J. Med. Microbiol., 2011, vol. 301, no. 4, pp. 282-292. doi: 10.1016/j.ijmm.2010.10.005

32. Tille P. Bailey \& Scott's diagnostic microbiology. St. Louis County: Elsevier Mosby, 2015. 1056 p.

\section{Авторы:}

Дерахшан С., к.н., Центр исследования печени и органов пищеварения, Курдский университет медицинских наук,

г. Сенендедж, Иран;

Резайи А., м.н., студенческий научно-исследовательский комитет, Курдский университет медицинских наук,

г. Сенендедж, Иран;

Мохаммади Ш., к.н., Исследовательский центр

зоонозов, Научно-исследовательский институт развития

здравоохранения, Курдский университет медицинских наук,

г. Сенендедж, Иран.

\section{Authors:}

Derakhshan S., PhD, Liver and Digestive Research Center, Research Institute for Health Development, Kurdistan University of Medical Sciences, Sanandaj, Iran;

Rezaee A., MSc, Student Research Committee, Kurdistan University of Medical Sciences, Sanandaj, Iran;

Mohammadi Sh., PhD, Zoonoses Research Center, Research Institute for Health Development, Kurdistan University of Medical Sciences, Sanandaj, Iran. 